\section{God og konsis innføring i epidemiologi}

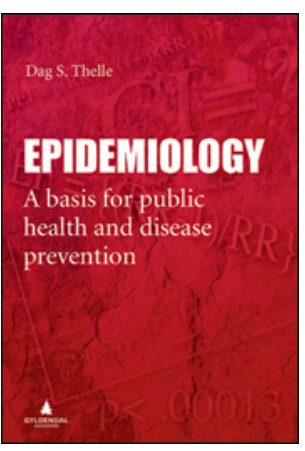

\author{
Dag S. Thelle \\ Epidemiology \\ A basis for public health and disease \\ prevention. 320 s, tab, ill. Oslo: Gyldendal \\ Akademisk, 2015. Pris NOK 425 \\ ISBN 978-82-05-41220-0
}

Det finnes en rekke gode lærebøker i epidemiologi, så det var noe nølende og med en viss skepsis jeg gikk med på å anmelde Dag S. Thelles bok. Jeg ble imidlertid positivt overrasket. Boken er ideell for medisinstudenter som en første introduksjon til faget, og passer også for travle leger og annet helsepersonell som en referansebok om grunnleggende begreper og fremskritt i faget. For den som planlegger en karriere innen epidemiologisk forskning, vil imidlertid mer utdypende bøker som omhandler de ulike emnene grundigere, være nødvendig.

I de første 12 av de 20 kapitlene har forfatteren rettet søkelyset mot epidemiologisk studiedesign og assosiasjonsmål, og han dekker viktige metodologiske problemer som mål for validitet og viktige feilkilder (bias). Han beskriver også paradigmeskiftet for hva som skal til for å kunne trekke kausale slutninger, som kom i 1960-årene da man forsøkte å forstå røykerelatert morbiditet og mortalitet. Boken dekker emner fra den akademiske litteraturen som mange ikke-spesialister ellers vil finne utilgjengelige og vanskelige å forstå, $i$ et forfriskende lett fordøyelig format, fylt med pedagogiske eksempler og figurer. Eksempler på emner som nevnes i oversiktsform, er Thomas Bayes' arbeid med betinget sannsynlighet, kausale grafer ved bruk av «directed acyclic graphs» (DAGs) og idégrunnlaget for mendelsk randomiseringsteknikk, som brukes i genetisk epidemiologi.

Forfatteren tar oss med på en tidsreise fra epidemiologiens opprinnelse med John Snows kolerastudier i London på midten av 1800-tallet, og videre gjennom de viktigste utviklingstrekk og utfordringer innen epidemiologi og folkehelse frem til i dag. Det hele er illustrert med metodiske problemstillinger. Han presenterer den skiftende sykdomsutbredelsen i ulike populasjoner mens han fremhever de epidemiologiske overgangene som har skjedd og fortsatt skjer. Videre gir han en overbevisende beskrivelse av sosiale ulikheter i helse og hvordan ulik sykdomsforekomst mellom og innen populasjoner kan gi ledetråder om underliggende årsaksfaktorer - faktorer som hvis de identifiseres, kan føre til effektive forebyggende tiltak. Betydningen av epidemiologi innen folkehelse og helsepolitikk fremheves, men forfatteren erkjenner og beskriver samtidig også fagfeltets begrensninger.

I tillegg til de 20 kapitlene inneholder boken tre vedlegg som kan være nyttige som grunnlag for klasseromsdiskusjoner. Forfatteren drar veksler på sin fremragende karriere innen undervisning i forebyggende medisin og epidemiologi og sin epidemiologiske forskning når han har forfattet denne boken.

Min konklusjon er at dette er en god og konsis innføring i epidemiologi.

\section{Norske lege- og tannlegestudenter i Basel}

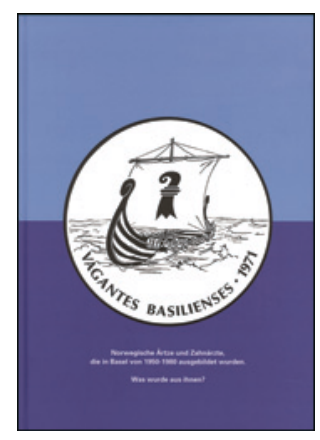

Even Sundal, Einar Svendsen,

Helene Torkildsen et al, red.

Norwegische Ärzte und Zahnärzte, die in

Basel von 1950-1980 ausgebildet wurden.

Was wurde aus ihnen?

300 s, ill. Basel/Tønsberg: Vagantes

Basilienses, AlumniMedizin Basel.

Pris NOK 400

ISBN 978-82-303-2990-0

Målgruppen er norske og sveitsiske leger, tannleger, deres etterkommere og alle med interesse for hvordan norske leger og tannleger de siste 60 årene fikk sin basisutdanning fra utenlandske lærersteder. Det medisinske fakultetet ved Universitetet i Basel immatrikulerte i en 30-årsperiode fra 1950 mer enn 150 lege- og tannlegestudenter fra Norge, og ga dem en grunnutdanning for lege- og tannlegeyrket. Tekstene er skrevet på tysk, og boken er trykt i rekken av Erzählte Erfarung der AlumniMedizin Basel i forbindelse med et fakultetsjubileum. Forordet er tankevekkende og handler om det ansvaret europeiske universiteter tok, for å gi innsatsvillige norske artianere muligheten til utdanning.

Hovedinnholdet er bibliografiene til 30 leger og 18 tannleger med portrettbilder. De øvrige 107 biografiene er tysk oversettelse av relevante tekster i Norges leger 1996 og Norges tannleger 1998. Enkelte biografier av 37 avdøde er skrevet av kolleger. Majoriteten av studentene er født mellom 1935 og 1955, og de kom til Universitetet i Basel fra hele Norge. Noen tok sin avsluttende eksamen i Tyskland eller i Norge. Her er informasjon om familiebakgrunn, skolegang i Norge og valg av studiested. Det var en god blanding av naivitet og pågangsmot ved ankomsten til Basel. Felles skjebne ga evigvarende vennskap, hvor de eldre norske studentene veiledet og hjalp de yngre studentene. Eksamener etter første studieår og «Staatsexamen» i 16 fag ga varige inntrykk. De sveitsiske medstudentene behersket tysk, fransk og italiensk, og i tillegg hadde mange hatt latin og gresk i gymnasiet. Nordmennene var derimot vinnere i sportslige studentaktiviteter. Det videre hendelsesforløpet etter sveitsisk «Staatsexamen» - giftemål, barn og faglige karriere er omtalt. Mange norske studentene har i ettertid følt seg som europeere, men med få unntak reiste de hjem til Norge for å praktisere. Flere omtaler tiden i Basel som det beste i livsløpet. I alt 17 av de norske studentene ble stimulert til en akademisk løpebane som professorer ved medisinske fakulteter i Norge og i utlandet.

Redaktørene har hatt et krevende arbeid med å samle inn biografiene. De har ikke vektlagt stram redigering og kildehenvisninger.

Boken er det første i sitt slag hvor man omtaler en hel gruppe norske lege- og tannlegestudenter ved et studiested utenfor Norge. Basel-studentenes erfaringer kan nok i noen grad generaliseres til norske studenter ved andre studiesteder i Sveits, Tyskland, Østerrike, Nederland og Storbritannia. Det er ønskelig at andre grupper av norske studenter ved andre universiteter i Europa samler erfaringene fra sine studieår. Det ville gi oss en større innsikt og forståelse av bakgrunnen til leger og tannleger i Norge på slutten av forrige årtusen. Det er god og spennende lesing, og jeg anbefaler boken varmt.

Amund Gulsvik

Professor emeritus, Klinisk institutt 2

Universitetet i Bergen 